\title{
Konflikt z perspektywy erystyki i eutoryki
}

\author{
Dorota Korwin-Piotrowska \\ Uniwersytet Jagielloński w Krakowie
}

\section{Conflict from the perspective of eristic and eutoric}

\begin{abstract}
The article analyzes conflict as a phenomenon connected with persuasion - close to disputes or quarrels, yet not identical with them. The background for the considerations encompasses works from various fields: sociology, linguistics, philosophy, and psychology, but rhetoric remains in the very center. The author characterizes its part dealing with absolute winning in disputes, i.e. eristic, and it presents a counterbalance to it and to the agonistic attitude. This complement is eutoric (author's own term) as a branch of rhetoric which concentrates on positive communication based on mutual listening, empathy and a constructive dialogue, which favors prevention of conflicts, or possibly resolving them. Eutoric has its source in philosophy of dialogue, pragmalinguistics, psychology of persuasion, as well as in the theory and practice connected with mediations and negotiations.
\end{abstract}

Key words: rhetoric, eutoric, eristic, conflict, dispute, linguistics, psychology of persuasion, philosophy of dialogue

Słowa kluczowe: retoryka, eutoryka, erystyka, konflikt, spór, lingwistyka, psychologia perswazji, filozofia dialogu

\section{Przestrzeń konfliktu i modelowanie relacji}

Przestrzeń konfliktu to przestrzeń, w której żyjemy. Aktualnie, bo wśród ludzi pełno jest konfliktów (tak na poziomie prywatnym, jak i społecznym, międzypaństwowym oraz globalnym), oraz potencjalnie, bo każda rozmowa, wymiana odmiennych racji i każde zdarzenie może stać się zarzewiem konfliktu.

Jak wiadomo z historii - zanim nastąpi kryzys w relacjach społecznych, najpierw „choruje” język ${ }^{1}$, co z kolei jest efektem, zazwyczaj nieuświadamianej, zmiany postawy względem innych. Zasada ta dotyczy jednak nie tylko dyktatur czy totalitaryzmu, lecz wszelkich relacji: przyjacielskich, rodzinnych, pracowniczych, klasowych, etnicznych, międzypaństwowych

${ }^{1}$ Dowodzą tego m.in. książki: V. Klemperer, LTI. Notatnik filologa, tłum. J. Zychowicz, Warszawa 1989 czy D. Ugresić, Kultura kłamstwa, tłum. D. J. Ćirlić, Wrocław 1998. 
czy globalnych. Podczas konfliktu - a konflikt jest zawsze stanem świadczącym o kryzysie relacji, prowadzącym albo do przesilenia, albo do zmiany układu sił, albo do dalszej eskalacji - wzmagają się antagonizmy, pojawia się myślenie spolaryzowane, następuje podział na ja lub my (czyli swoi, dobrzy) vs. ty lub oni (czyli źli bądź radykalnie obcy), a negatywne etykiety oraz myślowe schematy zastępują porozumiewanie się. Przypomina to sytuację sporu lub kłótni, dlatego warto może przyjrzeć się ponownie tym pozornie synonimicznym określeniom. Samo uświadomienie sobie, że istniejąca różnica racji może być nazwana którymś z tych pojęć lub mianem konfliktu, wpływa w pewien sposób na postrzeganie danej sytuacji i relacji międzyludzkich. Istnieje bowiem sprzężenie zwrotne między tym, jak o czymś myślimy, mówimy, tj. jak nazywamy zdarzenia i relacje - a tym, czym one dla nas są, lub nawet tym, czym się dzięki temu stają. Wstępne założenia, oceny i sądy, też wcześniejsze doświadczenia decydują o tym, jaki tryb retoryczny przyjmiemy i jaką uczynimy projekcję co do oponenta.

Podstawowe pojęcia związane z komunikacją międzyludzką scharakteryzowała przed laty z perspektywy lingwistycznej Anna Wierzbicka², wypróbowując do tego język pojęć podstawowych. Pisała, że w rozmowie chodzi o chęć „mówienia różnych rzeczy jeden do drugiego” i wzajemne założenie, że tego samego chce strona przeciwna. W dyskusji - że ktoś inny myśli co innego, uzasadnia swój sąd i oczekuje, że obie strony będą myśleć to samo. W sporze zaś uruchomione jest wartościowanie co do cudzego sądu, który uznaje się za zły i który chce się zmienić. W kłótni ktoś nie tylko uważa, ale też wprost mówi, że druga strona źle myśli - i żąda od niej, by się przyznała do tego. Z kolei Aleksander Wilkoń, rozpatrując współcześnie gatunki mówione ${ }^{3}$, charakteryzuje rozmowę w opozycji do uładzonej konwersacji. Pisze, że rozmowa opiera się na języku naturalnym, jest spontaniczna, dotyczy tematów codziennych i ma luźny układ tematów. Natomiast dyskusję badacz zestawia z kłótnią: tę pierwszą według autora cechuje panowanie nad emocjami, zachowanie tolerancji, czynnik współpartnerstwa i tendencja do przekonania rozmówcy, podczas gdy kłótnię - emocjonalność, nietolerancja, chęć dominacji i tendencja do obrażania rozmówcy.

Zupełnie inną panoramę kreśli Piotr H. Lewiński ${ }^{4}$, nawiązując do wielu dzieł retorycznych i lingwistycznych. Dzieli on dialogi na poznawcze (nieantagonistyczne, kooperatywne, oparte na udzielaniu informacji przez jedną ze stron), refleksyjne (dążące do rozpoznania i rozstrzygnięcia kwestii spornych - przykładem krytyczna dyskusja, narada, negocjacje) i ery-

${ }^{2}$ A. Wierzbicka, Genry mowy, w: Tekst i zdanie. Zbiór studiów, red. T. Dobrzyńska i E. Janus, Wrocław 1983, s. 131.

${ }^{3}$ A. Wilkoń, Gatunki mówione, w: Porozmawiajmy o rozmowie. Lingwistyczne aspekty dialogu, red. M. Kita i J. Grzenia, Katowice 2003, s. 48-49.

${ }^{4}$ P. H. Lewiński, Neosofistyka. Argumentacja retoryczna $w$ komunikacji potocznej, Wrocław 2012. Sporom i konfliktom poświęcone są też dwa tematyczne numery „Forum Artis Rhetoricae" z 2013 r. - Spór i retoryka to temat nr 1, a Konflikt i retoryka nr 2. 
styczne, które oparte są na agonie, traktowanym jako pojedynek. Wśród tych ostatnich autor wymienia debatę, agitację, uwodzenie, przesłuchanie oraz kłótnię, charakteryzując ją jako typ wypowiedzi skrajnie antagonistyczny, emocjonalny, wykorzystujący personalny atak i nieuznający porażki, choć cytuje też badania, w których dostrzega się różnice między kłótnią nieuczciwą a uczciwą (gdy jasno określa się problem, zapobiega eskalacji konfliktu i dąży na koniec do ugody ${ }^{5}$ - co by jednak oznaczało, moim zdaniem, przejście od kłótni do sporu). Agnieszka Budzyńska-Daca dzieli natomiast spory na publiczne, zawodowe i prywatne, wskazuje na różnice związane z celem oraz sposobami prowadzenia sporu - i wśród tych ostatnich wymienia zasady argumentacji, perswazję oraz manipulację, wskazuje też na wpływ przestrzeni prywatnej i publicznej na relacje między partnerami oraz na przebieg sporu, w tym wybór metod dialektycznych, retorycznych lub erystycznych ${ }^{6}$.

Zestawienia te pokazują, że antagonizm tkwiący w sporze czy dyskusji ulega przeobrażeniu podczas kłótni, gdy uruchomione zostają emocje i roszczenia wobec drugiej strony, prowadzące do silnej konfrontacji emocji, wyobrażeń i racji, czemu towarzyszy jakaś forma agresji. Dyskusje, spory czy kłótnie są poza tym związane z tematem, problemem, różnicą stanowisk - i są doraźną formą kontaktu słownego, mającą swój początek i koniec. Mogą więc zarówno prowadzić do konfliktu, jak być jego objawem, ale nie są z nim tożsame. Konflikt natomiast jest pojęciem szerszym, wykraczającym poza akt mowy - konflikty słowne są tylko częścią całego pola innych zjawisk opartych na społecznych antagonizmach. Poza tym nawet jeśli konflikt nie zamienia się w fizyczną agresję, to nie dotyczy jedynie słów i sytuacji - przenosi się na sferę postaw i działań (takich np. jak rezygnacja z kontaktu, wycofanie się, milczenie albo wejście w inną relację). Jest więc stanem obejmującym całościowo zaangażowane weń osoby czy grupy i nie kończy się - jak spór - rozstrzygnięciem. Chodzi w nim bowiem o sytuację, w której dwie strony wiedzą, że strona przeciwna myśli czy działa źle, ale nie przypuszczają, że da się to na drodze pokojowej perswazji zmienić. Kryje się za tym uznanie bezwzględnego antagonizmu (racji, postaw, aspiracji, światopoglądu, punktów widzenia) i jednocześnie właśnie nierozstrzygalności.

Zatem motorem konfliktu są: postrzegany brak możliwości zmiany i jednocześnie poczucie palącej potrzeby zmiany. Dlatego zwykle konflikty są długotrwałe - i albo wygasają z czasem, ale w każdej chwili mogą rozgorzeć na nowo, jeśli nie zmienią się okoliczności, albo są rozwiązywane z udziałem osób trzecich, rzadziej - decyzją samych oponentów, na mocy specjalnej umowy, ugody (np. ze względu na jakieś inne dobro albo grę zależności biznesowych czy politycznych bądź chęć uniknięcia nieprzyjemnych dla obu stron konsekwencji). Fundamentalna niezgodność leży bowiem

${ }^{5}$ P. H. Lewiński, dz. cyt., s. 264-265.

${ }^{6}$ A. Budzyńska-Daca, Eristic and Dispute - Applications and Interpretations, „Forum Artis Rhetoricae" 2013, nr 2, s. 7. 
u źródeł konfliktu (łac. conflictus to zderzenie), a jego cechami wtórnymi są intensywność (choć stopniowalna i zmienna w czasie) oraz - przynajmniej na pewnym etapie - wrażenie trwałego braku porozumienia. Rodzi się w ten sposób obraz drugiej strony jako rywala, przeciwnika czy wroga, w każdym razie kogoś skrajnie innego, którego głos należy wykluczyć bądź zdominować. Badania psychologiczne przekonują ponadto, że stanowisko równie intensywne, co nasze, wydaje nam się bardziej skrajne 7 . Wytwarza się w ten sposób dodatkowy mechanizm samonapędzający konfliktów - ich usprawiedliwieniem jest często rzekomy radykalizm strony przeciwnej.

Jak zauważa Magdalena Danielewiczowa, analizując to pojęcie z perspektywy lingwistycznej - „konflikt” odnosi się bardziej do stanu niż działania i do czegoś, co powstaje z reguły w sposób nagły, choć też może stopniowo narastać czy zmieniać swoje natężenie. W każdym razie to zjawisko zwykle rozciągające się w czasie. Autorka stawia tezę, że

konflikt zaczyna się zawsze w pewnej wspólnocie, rozerwanej w pewnym momencie grą sprzecznych interesów, te oceniane są jako zagrażające wartościom wyznawanym przez każdą z zantagonizowanych stron, wybucha, gdy niemożliwa jest dalsza rozmowa ${ }^{8}$.

Danielewiczowa twierdzi, iż dyskusje, polemiki, dysputy zmierzają do konkluzji, spory do porozumienia, kłótnie do zgody, ale konflikty wymagają rekonstrukcji relacji, czyli pojednania.

Badaczka jednak nie podaje, jak rozumie zgodę i pojednanie, tymczasem samo wygaśnięcie konfliktu między zwaśnionymi stronami albo zakończenie konfliktu wojennego przez zawarcie porozumienia co do pokoju nie jest tożsame z pojednaniem właśnie - zwykle ma ono charakter symboliczny i wymaga osobnego aktu (jak słynny list polskich biskupów do biskupów niemieckich). Na dodatek konflikty, które są rozwiązywane w mediacjach sądowych, kończą się z reguły porozumieniem, a więc racjonalną ugodą, niekoniecznie pojednaniem (zakładającym zwykle skruchę jednej ze stron lub obopólne przebaczenie win ${ }^{9}$ ). Z kolei „zwykłe” kłótnie czy konflikty rodzinne mogą kończyć się właśnie pojednaniem - na przykład w formie podania sobie dłoni czy wyznania uczuć. Rację ma natomiast Danielewiczowa, pisząc, iż uśmierzenie konfliktu wymaga ustanowienia relacji na nowo. Jak widać, blisko mu w tym do kłótni, która jednak zamyka się raczej w ramach jednego spotkania i aktu mowy, a dopiero w nadrzędnej sytuacji konfliktowej wszczynana jest na nowo.

Oczywiście wszystkie powyższe rozważania nie oznaczają, że konflikty z zasady są czymś złym. Podobnie jak spory czy kłótnie - konflikty są nie

${ }^{7}$ M. Tokarz, Ocena spoteczna - teoria i wnioski praktyczne, w: Mechanizmy perswazji i manipulacji. Zagadnienia ogólne, red. G. Habrajska, Łask 2007, s. 82-83.

${ }^{8}$ M. Danielewiczowa, Spierać się, kłócić, być w konflikcie. Rozważania semantyczne, w: Wspótczesne dyskursy konfliktu. Literatura - Język - Kultura, red. W. Bolecki, W. Soliński, M. Gorczyński, Warszawa 2015, s. 116.

${ }^{9}$ Por. I. Dziugieł, Mediacja w postępowaniu przygotowawczym, Szczytno 2004, s. 8-9. 
tylko po prostu częścią naszego życia, ale też mogą przyczyniać się do zmian prowadzących w dobrym dla danej relacji (interpersonalnej lub grupowej) kierunku. Pobudzaja do rozwijania własnych koncepcji, ujawniają skryte problemy, uczą określania swojego stanowiska, wyznaczania i korygowania granic, także kreatywnego myślenia i taktycznego działania, są źródłem wynajdowania lepszych rozwiązań, a zatem stymulują rozwój międzyludzkich relacji. Jednak - jak wiemy - nie każda dyskusja, tak jak nie każda krytyka i nie każdy spór czy kłótnia ma charakter koniec końców konstruktywny, przynoszący przydatną i uznaną za wartość zmianę. Jeszcze rzadziej dotyczy to konfliktów, ale z kolei nauka płynąca z ich rozwiązywania lub zapobiegania ich powstawaniu bądź eskalacji ludziom pomaga - daje szansę przywrócić komunikację i przybliżyć się do jakiegoś dobrostanu. A o tym, jak bardzo ten dobrostan w sytuacji konfliktu jest zachwiany, świadczą choćby metafory konceptualne - z używanych powszechnie figuratywnych wyrażeń i zwrotów wynika, że „konflikt to ogień” (skoro coś jest zarzewiem konfliktu, konflikt wybucha, tli się czy wygasa) lub ból (można go uśmierzyć, bywa ostry, może się jątrzyć, doskwierać).

Bliżej wpływem konfliktów na życie wspólnot zajmuje się już nawet osobna dziedzina o charakterze interdyscyplinarnym - polemologia ${ }^{10}$ (gr. polemos - wojna, konflikt, spór), powstała po II wojnie światowej. Czerpie ona wiedzę przede wszystkim z socjologii i psychologii, ale też wiedzy filozoficznej czy ekonomicznej oraz politologicznej dotyczącej życia społecznego. Jak pisze Janusz Sztumski, rekapitulując w 2000 roku socjologiczne dokonania analityków konfliktu: „Dotychczasowe badania uzasadniają twierdzenie, że konflikty społeczne są zjawiskami: normalnymi, wszechobecnymi, ciagtymi oraz użytecznymi" ${ }^{11}$. Inna jest perspektywa, lecz podobna końcowa konstatacja Chantal Mouffe, filozofki postmarksistowskiej, w książce poświęconej agonistyce ${ }^{12}$. Badaczka przyjmuje, że agoniczność jest pożyteczną i niezbywalną częścią życia społecznego i politycznego, dzięki której utrzymywana jest chwiejna równowaga przeciwstawnych sił. Autorka twierdzi nawet, że „Zbyt wielki nacisk na konsensus, łącznie z awersją do konfrontacji, wiedzie do apatii i niezadowolenia z politycznej partycypacji”, czego efektem jest niechęć wyborców do głosowania. I dalej - „Choć konsensus bez wątpienia jest konieczny, musi mu towarzyszyć niezgoda”, określając tego typu zalecany konsensus „konsensusem konfliktowym" ${ }^{13}$. Takie podejście, moim zdaniem, to swoiste signum temporis, będące w gruncie rzeczy tyleż wyrazem realizmu politycznego, co swego rodzaju zachętą do zaostrzania stanowisk.

\footnotetext{
${ }^{10}$ Termin socjologa Gastona Bouthoula.

${ }^{11}$ J. Sztumski, Konflikty spoleczne i negocjacje jako sposoby ich przezwyciężania, Częstochowa 2000, s. 8 [kursywa w cytacie pochodzi od autora książki].

${ }^{12} \mathrm{Ch}$. Mouffe, Agonistyka. Polityczne myślenie o świecie, przeł. B. Szelewa, Warszawa 2015.

${ }^{13}$ Tamże, s. 23.
} 
Wróćmy jeszcze do pracy Sztumskiego, mającej charakter wprowadzenia do polemologii. Autor pisze, iż podłożem konfliktu może być brak zgody w jakiejś sprawie, sprzeczność interesów, kolizja norm czy współzawodnictwo, lecz nie są to warunki wystarczające do powstania konfliktu społecznego, który jest walką, a nie tylko stwierdzeniem odmienności ${ }^{14}$. Badacz zauważa, że

Chociaż każdy spór jest zalążkiem sytuacji konfliktotwórczej, to jednak nie każdy z nich musi koniecznie doprowadzić do konfliktu [...] nawet ostra polemika [...] nie jest jeszcze utożsamiana z konfliktem tak długo, dopóki strony poprzestają na wymianie argumentów i na próbach weryfikacji wynikających z nich wniosków. Jeśli natomiast przejdą od argumentów do inwektyw lub innych działań wrogich [...] to wówczas istniejący spór przeistacza się w konflikt ${ }^{15}$.

Z punktu widzenia niniejszego wywodu istotne w pracy Szumskiego są zwłaszcza informacje o tym, że choć można wskazać szereg potencjalnie konfliktogennych zjawisk ${ }^{16}$, a także wymienić uwarunkowania społeczne, ekonomiczne, polityczne, ideologiczne i kulturowe konfliktów, to zaistnienie i eskalacja konfliktu zależą jeszcze zawsze od emocji, świadomości i osobistego zaangażowania ludzi ${ }^{17}$. Obiektywne uwarunkowania nie przesądzają więc o wybuchu konfliktu, choć znacząco zwiększają jego prawdopodobieństwo, natomiast decydujący jest poziom indywidualnej czy zbiorowej frustracji.

Również badania psychologów społecznych potwierdzają obserwacje dotyczące udziału zbiorowych emocji nie tylko w powstawaniu konfliktów, ale też ich zamianie $\mathrm{w}$ ciągnący się nieraz z pokolenia na pokolenie antagonistyczny proces. Wymienia się tu „pętlę: strach - gniew - agresja"18 oraz rolę specyficznego „zbiorowego filtra” w postrzeganiu sytuacji jako nierozwiązywalnego konfliktu zbiorowego. Tym filtrem jest nastawienie emocjonalne jakiejś zbiorowości, na które z kolei mają wpływ pamięć zbiorowa (w tym narracje i autonarracje, sposób nazywania uczestników konfliktu) oraz tzw. etos konfliktu (zbiór przekonań społecznych charakteryzujących daną sytuację i udział w niej własnej grupy, dający aktualny obraz sytuacji) wszystko to składa się, jak pokazuje Daniel Bar-Tal, na „infrastrukturę społeczno-psychologiczną", która przesądza o trwaniu konfliktu ${ }^{19}$.

Dalsze prowadzone tutaj rozważania dotyczyć będą tylko jednego aspektu związanego z polemologią, jakim jest rola języka, a szczególnie

${ }^{14}$ Tamże, s. 14-15.

${ }^{15}$ Tamże, s. 112.

${ }^{16} \mathrm{~J}$. Sztumski wymienia osiem tego typu obszarów, takich np. jak dysproporcje w rozwoju społecznym czy niedomaganie systemów komunikacji i informacji - zob. dz. cyt., s. 34-35.

${ }^{17}$ Zob. zwłaszcza s. 36 i nast. książki Sztumskiego, dz. cyt.

${ }^{18}$ M. Jarymowicz, D. Bar-Tal, Strach i nadzieja $w$ konfliktach międzynarodowych, zwanych nierozwiązywalnymi, w: Konflikty międzygrupowe. Przejawy, źródła i metody rozwiązywania, red. K. Skarżyńska, U. Jakubowska, J. Wasilewski, Warszawa 2007, s. 24.

${ }^{19}$ D. Bar-Tal, Społeczno-psychologiczne podstawy nierozwiązywalnych konfliktów, w: Konflikty międzygrupowe..., s. 94 i nast. 
retoryki, w przestrzeni konfliktu. Punktem wyjścia jest założenie, że choć konflikty są, realnie rzecz biorąc, nie do uniknięcia, to nie należy ich gloryfikować ani nawet tylko w pełni akceptować, bo to prowadzi do eksplozji antagonizmów, wykraczającej poza słowną agresję w stronę fizycznej walki, wojny - ale szukać możliwości ich przekształcania w konstruktywny dialog. Rację ma bowiem Ewa Domańska, gdy pisze, że „Potrzebujemy [...] przystosowanej do realiów współczesnego świata nauki o życiu razem"º.

Rola języka w kształtowaniu relacji i postaw jest zasadnicza. I jeśli słowami, jak uczy społeczne doświadczenie, można modelować relację tak, że zamienia się w konflikt, prowadząc przy tym do sporów i kłótni, walki czy zerwania kontaktu, to i w słowach przede wszystkim szukać należy źródła tego, co jest jego odwrotnością: porozumienia, kompromisu czy pojednania. Dużo zależy od nastawienia - zarówno do drugiej strony, jak i do samej kontrowersji, wokół której spór czy konflikt narasta, a także od wyrażenia akceptacji lub nie wobec sposobu nazwania przedmiotu sporu oraz wobec stylu, w jakim prowadzona jest dysputa. Nastawienie na podkreślanie różnic, kontrowersji, rozbieżności punktów widzenia i braku możliwości przyjęcia wspólnej perspektywy bądź używanych pojęć, również deklarowana niewiara w skuteczność rozmowy bądź niechęć do zawierania kompromisów modelują relację jako konfliktową, utrudniając zmianę podejścia na bardziej ugodowe i wprowadzając ramę poznawczą, w obrębie której rozmówca lub jakaś grupa przyjmują rolę wroga, przeciwnika czy konkurenta. Przyjrzyjmy się teraz mechanizmom językowym, które takiej postawie sprzyjają, a które proponuje erystyka, a następnie - rozważmy inne, niekonfrontacyjne pole retorycznych możliwości.

\section{Słowa, które dzielą - działanie erystyki}

W antyku perswazję erystyczną praktykowali sofiści, uczący posługiwania się antylogiami, sofizmatami oraz opierania argumentacji na prawdopodobieństwie bądź efektownym złudzeniu (np. Gorgiasz i Protagoras), także przedstawiciele filozoficznej szkoły megarejskiej, specjalizujący się zwłaszcza w paralogizmach i paradoksach (jak Euklides czy Eubulides) ${ }^{21}$. Przez całe wieki potem uprawiano antylogie (ćwiczenia w układaniu na zadany temat argumentów za i przeciw), uczono oratorskiego sprytu, organizowano pojedynki na argumenty i konkursy oratorskie. W ramach erystyki (gr. eris = niezgoda, kłótnia, eristikos = kłótliwy) uczono traktowania sporu

${ }^{20}$ E. Domańska, Historia egzystencjalna, Warszawa 2012, s. 190.

${ }^{21}$ Zob. M. M. Carrilho, Korzenie retoryki; starożytność grecka i rzymska, w: M. Meyer, M. M. Carrilho, B. Timmermans, Historia retoryki od Greków do dziś, red. M. Meyer, przeł. Z. Baran, Warszawa 2010; C. Mielczarski, Sofiści i polityka, Warszawa 2010, a także hasło z internetowego słownika filozoficznego: G. Duke, The Sofist (Ancient Greek), in: Internet Encyclopedia of Philosophy, http://www.iep.utm.edu/sophists/ (dostęp: 29.09.2016). 
w kategoriach walki na słowa - i wygrywania, także kosztem merytorycznych racji czy dochodzenia do prawdy, nie mówiąc już o uczuciach czy publicznym obrazie przeciwnika. Mamy więc wciąż żywą tradycję agoniczną w retoryce, przy czym warto przypomnieć, że słowo agon oznaczało zarówno pojedynek, walkę, jak i wszelkie współzawodnictwo, konkurencję ${ }^{22}$ - np. sportową czy artystyczną. I tak jak czym innym jest walka sportowa, oparta na regułach i niedążąca do uszkodzenia przeciwnika, lecz tylko eliminacji z gry, okazania przewagi w rywalizacji, a czym innym starcie na wojnie czy w chuligańskich bójkach, tak również w sztuce retorycznej i w intencjach erystycznych są widoczne różnice.

Oczywiście zarówno w wypadku ataku fizycznego, jak i słownego istnieje problem obrony koniecznej: jeśli ktoś próbuje kogoś za wszelką cenę zniszczyć lub naruszyć jakieś społeczne dobro, druga strona ma prawo się bronić, używając środków adekwatnych do danej sytuacji i skutecznych. Napaść słowna jest także formą przemocy - i tu erystyka podsuwa skuteczne sposoby obrony (przez atak i przez odparcie agresji podobną metodą). A zupełnie czym innym jest słowna „szermierka” dwóch równorzędnych, obdarzonych podobnymi erystycznymi umiejętnościami i nastawionych na agonistyczną grę partnerów ${ }^{23}$ - zabawa słowem, naciąganie znaczeń czy nawet stosowanie przytyków osobistych wśród znających się, przygotowanych do tego i uznających konwencję gry partnerów; również budowanie przez nich efektownych, a przez to łatwo rozpoznawalnych paralogizmów. To są jednak sytuacje wyjątkowe, z których nie można robić zasady ani przenosić ich na forum dowolnej grupy czy na działania publiczne i na codzienne konflikty, gdyż nikt nie jest w stanie zapanować nad reakcjami, emocjami, zmianami poglądów wszystkich świadków bądź uczestników sporu.

Nie da się też przewidzieć długofalowych skutków używania pewnych deprecjonujących czy fałszywych określeń, stosowania erystycznych chwytów do niszczenia kogoś, manipulacji, podstępnego manewrowania czyimś stanowiskiem czy argumentami oraz wpływania na opinię publiczną. Tym bardziej, że niektóre erystyczne „argumenty” (daję cudzysłów, bo argument to pogląd z uzasadnieniem, a tu raczej chodzi o opinię, pozór racjonalności, siłę amplifikacji) uderzają wprost w godność bądź wizerunek drugiej osoby. Nawet odwoływanie po czasie jakichś słów, pisanie lub wygłaszanie sprostowań albo przeprosin, tłumaczenie intencji, objaśnianie okoliczności nie wymaże wcześniejszego negatywnego efektu, zresztą nie zawsze nowa informacja dotrze do wszystkich zainteresowanych. Nie mówiąc już o tym, że zaangażowanie erystyczne i podziw dla własnej skuteczności zwykle wykluczają skruchę czy tylko refleksję co do realnych skutków per-

${ }^{22}$ Por. A. Rambiert, Bieg Pawła z Tarsu, czyli spotkania z greckq agonistyka, Wrocław 2013, https://depot.ceon.pl/bitstream/handle/123456789/6535/Bieg_Pawla_z_Tarsu_ czyli_spotkania_z_grecka_agonistyka.pdf?sequence=1\&isAllowed=y (dostęp: 29.09.2016).

${ }^{23} \mathrm{Na}$ ten aspekt erystyki jako gry - w odniesieniu do tradycji antycznej - zwraca też uwagę A. Budzyńska-Daca - zob. tejże, Eristic and Dispute..., s. 9. 
swazji. W skrajnych przypadkach erystyka przyznaje bowiem drugiemu człowiekowi rolę wroga, którego trzeba za wszelką cenę pokonać, a w mniej skrajnych - oponenta, któremu nie można pozwolić zakończyć sporu zwycięsko, albo też kogoś z jakiegoś powodu gorszego, komu trzeba pokazać, że tak jest postrzegany i takim go też przez to uczynić ${ }^{24}$. Takie założenia profilują model relacji oparty na nierównowadze, dominacji, a w niektórych przypadkach - preferowaniu konfliktu i przyzwalaniu na słowną agresję czy upokarzanie. Widoczny jest tu brak dobrej woli do przyjęcia pod rozwagę innego stanowiska, co samo w sobie już sprzyja konfliktom. Barierą, za którą czai się zło, jest czyjaś krzywda lub niszczenie pozytywnych społecznych wartości (jak wzajemne zaufanie, szacunek dla człowieka czy prawa). Konflikty, prowadząc do sytuacji zderzenia, walki, potencjalnie zmierzają do przekroczenia tej granicy, dlatego ignorowanie, pomniejszanie konsekwencji lub pochwała konfliktów i środków im służących jest czymś, moim zdaniem, nieodpowiedzialnym.

Czasom nowoczesnym erystykę przypomniał, jak wiadomo, w XIX wieku Artur Schopenhauer. Niemiecki filozof odnowił i wypunktował zabiegi, którymi się może posłużyć wprawny retor - w oryginale rozprawy jednak raczej chodziło o świadomość istnienia manipulacji i obronę przed nią. Autor też wyraźnie pisał o tym, że „dialektyka erystyczna”, jak ją określał, „to sztuka dyskutowania w taki sposób, aby zachować pozory racji, a więc per fas et nefas" ${ }^{25}$. Zatem ani o rację, ani o prawdę w niej faktycznie nie chodzi - ta świadomość pozoru i posługiwania się zarówno „dozwolonymi”, jak i „niedozwolonymi” środkami wydaje mi się tutaj szczególnie ważna. Tymczasem od momentu wydania Erystyki, czyli sztuki prowadzenia sporów, a więc od lat sześćdziesiątych XIX wieku ${ }^{26}$, z każdą dekadą dzieło to nie tylko obrastało i obrasta w coraz to nowsze przykłady i komentarze, ale także obejmuje swoim wpływem coraz szerszy obszar. Oznacza to, że oddajemy „pozorowi racji” coraz większe terytorium. I że w dzisiejszym świecie mniej cenimy porozumienie, konsensus czy kompromis, a bardziej - doraźny spór, kłótnię czy nieustanne pozostawanie w konflikcie. Praktyczna wiedza z zakresu erystyki używana jest nie tylko podczas prywatnych i publicznych zatargów, lecz także w całych strefach ludzkiej działalności, takich jak marketing, media, propaganda, prawo, sport czy polityka, uniemożliwiając prawdziwą dyskusję.

${ }^{24}$ Por. J. Wasilewski, Agon, czyli walka o dominację, w: tegoż, Retoryka dominacji, Warszawa 2006.

${ }^{25}$ A. Schopenhauer, Erystyka, czyli sztuka prowadzenia sporów, przeł. B. i L. Konorscy, wyd. III, przedm. T. Kotarbiński, Kraków 1984, s. 25. Por. A. Budzyńska-Daca i J. Kwosek, Erystyka, czyli o sztuce prowadzenia sporów. Komentarze do Schopenhauera, Warszawa 2011.

${ }^{26}$ Erystyka Schopenhauera została napisana w 1830 r., lecz wydana po śmierci autora. Ukazało się kilka różnych wariantów, pierwsze wydanie pochodzi z roku 1864. Zob. Uwagi wstępne tłumaczy do powyższego wydania. 
Dodajmy jednak od razu gwoli sprawiedliwości, że świadomość funkcjonowania chwytów erystycznych sprzyja analizie i wychwytywaniu intencji zawartej w tekstach perswazyjnych, badaniom nowomowy, odkrywaniu zagrożeń związanych z propagandą, ujawnianiu metod manipulacji w codziennej komunikacji i w relacjach wewnątrzspołecznych oraz międzypaństwowych. Zapobiega to uwiarygodnianiu się pokrętnych, przesadnych czy wręcz po prostu złych moralnie praktyk, a czasem może je powstrzymać - gdy ktoś ujawni podejrzane intencje, nazwie strategię. Poza tym, wiedząc o takich zabiegach i ich skutkach, łatwiej zauważyć źródło dominacji i ostrzec przed językowymi symptomami rodzenia się dyktatur i totalitaryzmów, wrogości etnicznych czy nastrojów wojennych, a także wszelkich dyktatów (od mody po jedynie słuszny pogląd na świat). Czyli de facto erystyka po części służy samoobronie, świadomość jej oddziaływania wzmacnia bezpieczeństwo obserwujących spory lub w nie bezpośrednio zaangażowanych, bo dzięki niej wiadomo, kiedy przekraczane są granice. Pomaga również ujawnić ludzkie słabości czy błędy w rozumowaniu. Jak pisał Tadeusz Kotarbiński - „trzeba wiedzieć, jak można pomóc sobie lojalnie w obronie słusznej sprawy i na co się może zdobyć nielojalny sprytny przeciwnik” ${ }^{27}$. Ten sam autor zresztą wydzielił „chwyty czysto techniczne” i „fortele nielojalne”, a dla równowagi dodał w swojej książce Charakterystykę dyskusji rzeczowej. Takie podejście - wraz z włączeniem erystyki w obręb wszelkich sztuk walki i rywalizacji, lączonych w agonistykę - jest dowodem, że filozof postrzegał samą erystykę jako dziedzinę opartą na konflikcie i wymagająca dopełnienia przez konstruktywne propozycje ${ }^{28}$.

Współcześnie erystyka ma wyraźne tendencje do ewoluowania w niedobrym kierunku. Staje się niebezpieczną modą, a posługujący się nią ludzie używają języka wypaczonego przez agresję i potrzebę rozpalania konfliktu. Cechuje ich takie postrzeganie świata, w ramach którego jest on oparty wyłącznie na antagonizmach i ciągłej walce wszystkich ze wszystkimi, ale przede wszystkim na starciach bilateralnych. Sprowadzenie problemów do czarno-białych ostrych opozycji jest bowiem najlepszym sposobem na zaognienie sytuacji oraz wywołanie konfliktu i zasugerowanie, że prawda jest tylko po jednej stronie, zatem musi być jakiś zdecydowany zwycięzca w sprawie i ktoś, kto ma być pokonany. $Z$ takim założeniem łączy się podejście do innych ludzi jako niegodnych zaufania, zawsze coś knujących przeciwników, którzy w związku z tym często są z góry pozbawiani części ludzkich pozytywnych właściwości (godności bądź wiedzy, podatności na zranienie, pełni praw obywatelskich itd.). $\mathrm{W}$ tej sytuacji właśnie wzajemna nielojalność, na którą zwrócił uwagę polski filozof, staje się cechą nadrzędną

${ }^{27}$ T. Kotarbiński, Definicja i cel studiowania erystyki. Chwyty czysto techniczne. Fortele nielojalne. Charakterystyka dyskusji rzeczowej, w: tegoż, Kurs logiki dla prawników, Warszawa 1961, s. 183-189.

${ }^{28}$ Inaczej charakteryzuje stanowisko filozofa Agnieszka Budzyńska-Daca, nawiązując jeszcze do Prakseologii Kotarbińskiego - zob. tejże, Eristic and Dispute..., s. 15. 
komunikacji. Powoduje ona samonapędzający się mechanizm sprzyjający konfliktom: zakładane przez podejrzliwość złe intencje innych zwalniają z moralnej odpowiedzialności za słowa, a nawet z potrzeby wysłuchania czyichś racji do końca, bo zanim jeszcze jakikolwiek spór się rozwinie, trzeba od razu okazać swą wyższość. Z kolei przyjęty język dominacji uniemożliwia uznanie czyichś argumentów czy obrazu świata, przyznanie się samemu do błędu czy tylko rozważenie nowych opcji albo powstrzymanie się od pochopnych opinii.

Istnieją nawet podręczniki oraz szkolenia, które służyć mają bezwzględnej i cynicznej walce nastawionej za wszelką cenę na wygraną (nie odsyłam do nich, by nie rozpowszechniać tych złych praktyk). Tak więc erystyka okazuje się obecnie nie tylko mocno ekspansywna, lecz widać w jej ramach wręcz aprobatę dla ostrej, bezpardonowej słownej konfrontacji. Do częstych zachowań publicznych należą: naruszanie strefy komfortu oraz wywieranie negatywnej presji na drugą osobę, osaczanie, obrażanie i zastraszanie, też wywoływanie i utrwalanie konfliktu, a nawet przyzwolenie na „mowę nienawiści”29. Tymczasem, przypomnijmy, podstawą dosłownie rozumianych, fizycznych sztuk walki są treningi uczące opanowywania własnej agresji i niepozwalania sobie na poddanie się prowokacji ze strony przeciwnika, a więc minimalizowanie niepotrzebnego wydatkowania energii - sztuki walki słownej poszły w odwrotną stronę. Dzięki mediom jesteśmy właśnie, na masową skalę, świadkami ich oddziaływania.

I tu znów warto przywołać Kotarbińskiego, który pisał, że erystyka to „sztuka prowadzenia sporów tak, aby wygrać spór w obliczu osób rozstrzygających”. Słowa pokazują także ważny czynnik, który być może decyduje o współczesnym powodzeniu erystyki. Powszechność kamer i mikrofonów, błyskawiczne przekazywanie przez dziennikarzy wypowiadanych słów i sądów, globalny zasięg Internetu powodują, że wszyscy staliśmy się świadkami, uczestnikami, kibicami i oceniającymi spory innych, w skali mikro i makro - od potyczek znajomych na forach po poważne konflikty międzynarodowe ${ }^{30}$. Milczenie i wstrzemięźliwość w sądach oraz czas na namysł bądź ochłonięcie i ułożenie dyplomatycznej odpowiedzi, też rodzaj samoograniczenia, spowodowany moralną dyscypliną - przestały być czynnikami wpływającymi na wszelkiego rodzaju dyskusje i spory. Toczą się one bowiem już nie w mniej lub bardziej zamkniętych gronach, grupach, jak

${ }^{29}$ Zob. np. D. Bychawska-Siniarska, Mowa nienawiści - definicja problemu, http:// docplayer.pl/15632849-Mowa-nienawisci-definicja-problemu-dominika-bychawskasiniarska.html (dostęp: 15.10.2016); S. Kowalski, M. Tulli, Zamiast procesu. Raport o mowie nienawiści, Warszawa 2003. Por. M. Głowiński, Retoryka nienawiści, „Nauka” 2007, nr 2; J. Puzynina, Mowa nienawiści a etyka stowa ZES, http://www.etykaslowa.edu.pl/wp-content/uploads/2016/o5/Mowa-nienawi\%C5\%9Bci-a-etyka-s\%C5\%820wa.pdf (dostęp: 27.09.2016). ZES to Zespół Etyki Słowa - powołany w 2016 r. przez Radę Języka Polskiego PAN (http://www.etykaslowa.edu.pl/).

${ }^{30}$ Por. M. Pietrzyk, Wolność artystyczna a tolerancja, w: tejże, Retoryka tolerancji, Warszawa 2015, s. 19. 
to dawniej bywało, lecz wobec ogromnej liczby „rozstrzygających”, a więc wobec widzów, słuchaczy, forumowiczów, użytkowników rozmaitych komunikatorów. Medialny efekt obliczany jest z uwzględnieniem potencjalnej przychylności odbiorcy (czasem masowego) i stopnia spektakularności konfliktu, czyli atrakcyjności dla obserwatorów. Dlatego zażarty, nawet sztucznie podsycany spór wydaje się czymś bardziej godnym pożądania niż przygotowana merytorycznie, wieloaspektowa dyskusja - co dokumentuje w swojej książce Cywilizacja kłótni Deborah Tannen ${ }^{31}$. Co gorsza, właśnie owo przerysowanie prowadzić może do zamiany jednorazowej kłótni w głębszy i długotrwały konflikt - nie tyle oparty na racjach, ile na emocjach oraz na wywołanym przez nie obrazie relacji jako właśnie relacji dogłębnie konfliktowej.

W ostatnim stuleciu erystyka rozwijana jest świadomie także przez osoby interesujące się ciemną lub przynajmniej dwuznaczną moralnie stroną retoryki: czarnym PR-em, socjotechniką, różnymi metodami manipulacji i pozyskiwania klienta, słuchaczy, czytelników czy widzów. Erystyka razem z wiedzą psychologiczną, socjologiczną i lingwistyczną daje do ręki narzędzia tzw. spin doktorom i specjalistom od wywierania wpływu na ludzij ${ }^{32}$. Przekazują je oni politykom, rzecznikom prasowym różnych instytucji, zawodowym propagandzistom, ale też coachom, dyskutantom telewizyjnym, sprzedawcom, mówcom motywacyjnym itd. Korzystają z niej także, niestety, wszelcy spragnieni władzy nad innymi ludźmi manipulatorzy, demagodzy, oszuści oraz zwykli hejterzy.

Innym, wychodzącym już poza erystykę, źródłem informacji na temat możliwości wpływania na ludzi za pomocą języka jest tzw. neurolingwistyczne programowanie ${ }^{33}$. To dziedzina zajmująca się technikami manipulacji opartymi na wiedzy językoznawczej i psychologicznej z zakresu kognitywistyki i pragmalingwistyki, także na teorii sugestii i hipnozie, wywodząca się z różnych terapeutycznych działań ${ }^{34}$. Co roku pojawia się wiele nowych pozycji z zakresu NLP - głównie w formie książek instruk-

${ }^{31} \mathrm{D}$. Tannen, Cywilizacja kłótni. Jak powstrzymać amerykańskq̨ wojnę na stowa, przeł. P. Budkiewicz, Poznań 2003.

${ }^{22}$ Zob. M. Kochan, Pojedynek na stowa. Techniki erystyczne $w$ publicznych sporach, Kraków 2005; W. Jabłoński, Kreowanie informacji. Media relations, Warszawa 2007. Por. B. Dobek-Ostrowska, J. Fras i B. Ociepka, Teoria i praktyka propagandy, Wrocław 1999; Ideologie $w$ stowach i obrazach, red. I. Kamińska-Szmaj, T. Piekot, M. Poprawa, Wrocław 2008; Sztuka perswazji. Socjologiczne, psychologiczne i lingwistyczne aspekty komunikowania perswazyjnego, red. R. Karpiel i K. Leszczyńska, Kraków 2004.

${ }^{33}$ Liczba książek z tego zakresu nieustannie rośnie, jedną z nowszych i bardziej wyważonych pozycji na naszym rynku jest: J. O'Connor, J. Seymour, NLP. Wprowadzenie do programowania neurolingwistycznego, przeł. B. Mizia, Poznań 2013. Por. A. Batko, Sztuka perswazji, czyli język wpływu i manipulacji, Gliwice 2005.

${ }^{34} \mathrm{O}$ historii NLP i kierunkach jego rozwoju pisze krytycznie Adam Skibiński - zob. tegoż, Perswazja etycznie neutralna? Od retoryki do meta-NLP, w: Retoryka i etyka, red. B. Sobczak i H. Zgółkowa, Poznań 2009, s. 89-91. Por. P. H. Lewiński, dz. cyt., s. 221-245. 
tażowych, poradników. Przynoszą one korzyść w postaci informacji o tym, jak różnie postrzegamy świat ${ }^{35}$, a równocześnie, jak podobnie reagujemy na pewne konstrukcje składniowe czy leksykalne, nawet tak drobne, jak spójniki - co ma wpływ na przebieg perswazji. Jednak poradniki NLP lansują także bardzo niebezpieczne przekonanie, że możemy z powodzeniem panować nad zachowaniami i reakcjami drugiego człowieka, narzucać za pomocą języka pożądane przez siebie reakcje, zmieniać mentalne ramy, w obrębie których interpretowane jest dane zjawisko, sterować emocjami. Słowem, że nie trzeba liczyć się z pragnieniami lub uczuciami innych ludzi, bo po prostu można je zmienić bądź nad nimi zapanować; wystarczy znajomość kilku trików. Daje to silny perswazyjny efekt marketingowy samemu NLP i rzeczywiście właśnie w marketingu ta wiedza jest najczęściej pożytkowana, a ponadto jej aplikowanie do innych dziedzin (zarządzania, poradnictwa interpersonalnego, propagandy politycznej, sztuki uwodzenia) zamienia je w marketing, sprowadzając wszystko do sprytnej, sugestywnej sprzedaży dowolnych idei innym osobom i odbierania im możliwości autonomicznego podejmowania decyzji. Psychologia perswazji sama została sprowadzona do roli zestawu poręcznych uniwersalnych narzędzi perswazyjnych, będących w gruncie rzeczy wytrychami, którymi rzekomo można poradzić sobie z każdą osobą i sprawą ${ }^{36}$.

Jesteśmy zatem, na początku XXI wieku, w sytuacji, w której niezwykle łatwo jest - na skalę prywatną czy lokalną lub, co gorsza, globalną - wpływać słowem na wiedzę, opinie, poglądy, wyobrażenia i decyzje innych ludzi. A to oznacza również możliwość wywoływania i podtrzymywania, nasilania oraz przenoszenia $\mathrm{w}$ inne rejony (tematyczne, emocjonalne, problemowe i geograficzne) konfliktów, „zarażania” nimi. Konflikty mogą być też dowolnie „hodowane” i wyolbrzymiane, choćby przez stosowanie słownych kontrastów: silne etykiety wskazujące „kata” i „ofiarę”, „winnych” i „niewinnych”, „swoich” i „obcych”, a także głośno snute przypuszczenia, domniemania, fabrykowane konsekwencje, posługiwanie się hiperbolą wobec czyichś przewin, a litotą wobec własnych itd. Wystarczy grupa, często specjalnie opłacanych w tym celu, osób aktywnie działających na forach internetowych, by rozsiewać nienawiść za pomocą rzekomo spontanicznych komentarzy, w celu radykalnej zmiany opinii publicznej na jakiś temat. Możliwości manipulacji ze strony formalnych i nieformalnych jednostek oraz grup jest mnóstwo. Mają bowiem do dyspozycji nie tylko klasyczne „fortele nielojalne” (takie jak wprowadzanie w błąd, powodowanie zamętu, niejasności, stosowanie wyrażeń wieloznacznych, posługiwanie się szyder-

35 Tego dotyczą na przykład filtry poznawcze, jakimi są tzw. metaprogramy - zob. J. O'Connor, J. Seymour, NLP..., s. 215-226.

${ }^{36}$ Zob. np. K. Hogan, Psychologia perswazji. Strategie i techniki wywierania wptywu na ludzi, przeł. A. Dziuban, Warszawa 2005. Hogan jest także autorem poradnika pod wiele mówiącym tytułem: Nauka perswazji, czyli jak w 8 minut postawić na swoim, tłum. J. Grabiak, Poznań 2007. W podobnym duchu pisze wciąż nowe książki Andrzej Batko. 
stwem, zohydzanie przeciwnika, używanie argumentów ad personam ${ }^{37}$ ), lecz także możliwość użycia ich i nagłośnienia przez masowe media. Jak również - wzmacniania czy zwielokrotniania tego działania za pomocą taktyk, które by należało nazwać erystyką wizualną ${ }^{38}$. To broń, która w rękach nieodpowiedzialnych ludzi może powodować społeczną katastrofę o dowolnej skali, zresztą nowoczesna wojna informacyjna na świecie już trwa ${ }^{39}$.

Trzeba jeszcze dla jasności podkreślić, że to nie sama erystyka - jako wiedza o tym, co się przydarza ludzkiej komunikacji językowej podczas sporu - jest z zasady konfliktogenna, lecz bezkrytyczne i amoralne posługiwanie się nią. Podobnie jak historia jako znajomość faktów, w tym tych dotyczących sporów granicznych, podziałów politycznych bądź wojen, sama wojen nie powoduje, lecz może być wykorzystywana do ich prowokowania. Problem jednak w tym, że erystyka jest nie tyle dyscypliną wiedzy, ile od początku, razem z całą retoryką - umiejętnością, czyli téchne - i coraz częściej do zestawu „chwytów” jest sprowadzana, a zabiegi te z założenia nie prowadzą do pokoju, ergo: służą konfliktom, pogłębiając antagonizmy i wywołując emocje. Świadome stosowanie „brudnych chwytów” tylko dlatego, że inni je stosują - lub dla satysfakcji z podjęcia "gry” bądź z przyjemności zaogniania konfliktu i dokuczania innym - to przejawy lekkomyślności, cwaniactwa, pychy czy złośliwości albo po prostu cynizmu, prowadzące do niszczenia społecznego dobra, jakim jest międzyludzka komunikacja. Coraz częściej, niestety, o chwytach tych mówi się jako o nieuniknionej konieczności ${ }^{40}$, myląc przyczynę ze skutkiem i uruchamiając $\mathrm{w}$ ten sposób mechanizm samospełniającej się przepowiedni - założenie konfliktu, walki powoduje, że trzeba wejść w spór jako element sytuacji konfliktowej o charakterze zero-jedynkowym i niszczyć „wroga”.

\section{Słowa, które łączą - działanie eutoryki}

Retoryka jako taka ukierunkowana jest na perswazyjną skuteczność, której podstawą jest szukanie odpowiedniości między tematem, sytuacją, stylem, taktem, typem słuchacza a całą wypowiedzią i typem argumentacji. Takie retoryczne umiejętności wystarczają do dyskutowania, również

${ }^{37}$ Zob. T. Kotarbiński, dz. cyt., s. 187.

${ }^{38}$ Ukazuje się ona w formie rozpowszechnianych, a wyraźnie nacechowanych negatywną perswazją, zdjęć i fotomontaży, filmów, memów, virali, też tworzonych pomników, rysunków, obrazów, wystaw, organizowanych manifestacji, happeningów, pokazów siły itp.

${ }^{39}$ Zob. np. J. Darczewska, Anatomia rosyjskiej wojny informacyjnej. Operacja krymska - studium przypadku, Warszawa 2014, http://www.osw.waw.pl/sites/default/files/ anatomia_rosyjskiej_wojny_informacyjnej.pdf (dostęp: 30.09.2016); A. Pratkanis, E. Aronson, Wiek propagandy. Używanie i nadużywanie perswazji na co dzień, tłum. J. Radzicki i M. Szuster, Warszawa 2003.

${ }^{40}$ Por. J. Stelmach, B. Brożek, Rehabilitacja erystyki, w: tychże, Negocjacje, Kraków 2014, s. 123-133. 
wtedy, kiedy pojawia się jakaś trudność w dialogu, merytoryczny spór czy nieporozumienie albo gdy istnieje potrzeba zabłyśnięcia, przekonania wahających się czy tylko sprawnego zrelacjonowania sprawy, przedstawienia argumentacji, atrakcyjnego opowiedzenia historii. Jednak aby zapobiec konfliktom, uniknąć ich eskalacji, nauczyć się porozumiewać możliwie skutecznie, rozwijać budujący dialog, doprowadzić do kompromisu lub tylko akceptacji tego, co obce, szukać takich dróg do drugiego człowieka, by nie czuł się osaczony, zniewolony, by pozwolić mu zachować godność - do tego trzeba już retoryki specyficznie sprofilowanej. Takiej, która miałaby zupełnie inne założenia niż erystyka - właśnie nie przeciwne, bo nie chodzi o poddawanie się, bezradność w sytuacjach konfliktowych czy idealistyczne zakładanie wyłącznie harmonii, miłości i pokoju w międzyludzkich relacjach, gdyż to prowadziłoby do niebezpiecznej w skutkach utopii.

W książce pt. Biate znaki ${ }^{41}$ nazwałam tę potrzebną część retoryki eutoryką (gr. eu = dobry). To sztuka takiego działania słownego, które nastawione jest na porozumienie, nawiązanie relacji, ustępstwo czy kompromis - stanowi więc niezbędną codzienną przeciwwagę dla erystyki. Eutoryka zakłada życzliwość, chęć wysłuchania oponenta, a jednocześnie możliwość zmiany własnego stanowiska, co wymaga też krytycznego podejścia do samego siebie. Zadaniem eutoryki jest dociekanie, jak stworzyć warunki, by nie powodować czyjejś konfuzji, nie eskalować konfliktu czy pozwolić sobie nawzajem na namysł bądź autokorektę - a przez to „zachować twarz" i dawać sobie wzajemnie poczucie komfortu, mimo sporu czy tylko różnic w postrzeganiu jakiegoś zjawiska. I choć w gruncie rzeczy eutoryka ma równie długą tradycję, jak erystyka, nie doczekała się nawet nazwy - jej istnienie jest „ciche”, jakby stanowiła oczywistą lub nieistotną część zwykłego retorycznego wyposażenia. Może dzieje się tak dlatego, że eutoryka zawsze zmierza do rozwiązań konstruktywnych, wyraźnie dąży do mediacji, budowania mostów, a to wymaga spokoju, namysłu, czasu na milczenie i znalezienie odpowiedniej reakcji, jak również pewnej dyscypliny, samoograniczenia, które są wartościami trudnymi do upowszechniania. Pewną trudnością i zarazem zaletą eutoryki jest jej wymiar etyczny lub dokładniej agatologiczny (gr. agathón - dobro) czy nawet - intencjonalnie, a więc poprzez nakierowanie, zmierzanie ku - aretyczny (od gr. areté, czyli cnoty, łączonej w antyku z dzielnością i samodoskonaleniem). Wątki te wyraźnie ujawniają się w filozofii dialogu (u takich autorów, jak Martin Buber, Emmanuel Lévinas), a na polskim gruncie szczególnie w nawiązującej do niej filozofii egzystencjalnego dramatu Józefa Tischnera ${ }^{42}$.

Oczywiście przez całe wieki istniała myśl filozoficzna, a później także psychologiczna i lingwistyczna dotycząca tego, jak się dobrze komunikować, jak prowadzić dialog czy owocną dyskusję. Refleksja eutoryczna stała się

${ }^{41}$ D. Korwin-Piotrowska, Białe znaki. Milczenie $w$ strukturze i znaczeniu utworów narracyjnych, Kraków 2015, s. 102.

${ }^{42} \mathrm{~J}$. Tischner, Filozofia dramatu. Wprowadzenie, Paris 1990. 
jednak mocniej widoczna dopiero w XX wieku, jako reakcja na dramatyczne wypadki historyczne, rozwój totalitaryzmów i ekspansję propagandy, ale też jako efekt rozwoju psychologii, lingwistyki, filozofii, socjologii, antropologii i antropologii kulturowej, a także etologii, neurobiologii czy nauk kognitywnych. Elementy eutoryki lub informacje służące lepszemu poznaniu podstaw językowego porozumiewania się znaleźć można - poza retoryką - we wspomnianej wcześniej filozofii dialogu, nauce o komunikowaniu się, psychologii perswazji, teorii negocjacji oraz teoretycznych podstawach mediacji społecznych, także opracowaniach na temat zjawiska empatii czy zasad kooperacji w grupie oraz dotyczących związków między percepcją a językiem. Niezwykle przydatne okazują się pragmalingwistyka, pragmadialektyka czy teoria konwersacji - określające zasady fortunności aktów mowy, kooperacji i grzeczności językowej, warunki skutecznej dyskusji, przypominające o funkcji milczenia czy przemilczeń w komunikacji, roli ram modalnych, społecznych skryptów, stereotypów, sugestii, kłamstwa, tabu, ale też o proksemice i komunikacji pozawerbalnej w całości przekazu ${ }^{43}$. Warto ponadto wskazać obszar niezwykle pomocny, którym jest kształtująca się dopiero antropologia słowa, wskazująca na różnorodność przekazów, w tym komunikatów językowych, ich zanurzenie w kulturze i powiązanie z medium, rolę schematów i słownych rytuałów w wytwarzaniu znaczeń, w tym także kulturowych modeli narracji, dialogu czy kłótni ${ }^{44}$. Oprócz wiedzy teoretycznej i opracowań naukowych istnieją także setki rozmaitych poradników dotyczących mediacji w sytuacjach kryzysowych, kłopotów wychowawczych, rozmów terapeutycznych, zapobiegania agresji i kłótniom w rodzinie czy szkole, poświęconych pracy z osobami trudnymi, chorymi, konfliktowymi, a także z ludźmi z innych kręgów społecznych i krajów. Uczą one konieczności uwzględniania różnic percepcyjnych, odmiennych zasad grzeczności i zachowań słownych uznawanych za poprawne i niepoprawne w tych różnych kręgach.

Zapleczem dla eutoryki jest zatem z jednej strony po prostu etyka słowa, której podstawą jest, jak to ujmuje Andrzej Markowski, „podmiotowe, a nie instrumentalne traktowanie się partnerów dialogu" oraz prowadzenie dialogu na zasadach prawdomówności, uprzejmości, wolności wyboru i braku dominacji, wzajemnej dobrej woli ${ }^{45}$. $\mathrm{Z}$ drugiej - interdyscyplinarna wiedza

${ }^{43}$ Zob. np. S. C. Levinson, Pragmatyka, przeł. T. Ciecierski, K. Stachowicz, Warszawa 2010; M. Tokarz, Sztuka dyskutowania, w: tegoż, Argumentacja. Perswazja. Manipulacja, Gdańsk 2006; P. H. Lewiński, dz. cyt., s. 26-40 i 62-72; A. Awdiejew, Strategie konwersacyjne, „Acta Universitatis Lodziensis. Folia Literaria Polonica” 2005, $\mathrm{nr} 7$.

${ }^{44}$ Zob. np. Antropologia słowa. Zagadnienia i wybór tekstów, red. i wstęp G. Godlewski, oprac. G. Godlewski, A. Mencwel, R. Sulima, Warszawa 2003. Por. Z. Kövecses, Porzq̨dkowanie wiedzy o świecie. Ramy $w$ umyśle, w: tegoż, Język, umyst, kultura. Praktyczne wprowadzenie, przeł. A. Kowalcze-Pawlik, M. Buchta, Kraków 2011, r. 5; Narracja jako sposób rozumienia świata, red. J. Trzebiński, Gdańsk 2002.

${ }^{45}$ A. Markowski, Kultura języka polskiego. Teoria. Zagadnienia leksykalne, Warszawa 2005 . 
pozwalająca zrozumieć źródła trudności w porozumiewaniu się, tkwiące zarówno w samym języku, jak i w psychice ludzkiej, właściwościach poznawczych człowieka oraz w okolicznościach ${ }^{46}$. Rzecz jasna samo uświadomienie sobie różnorodności ludzkich zachowań oraz ich etiologii nie zapobiega z góry sytuacjom konfliktowym - sprzyja jednak ich ograniczeniu oraz pokojowemu rozwiązywaniu bądź wyciszaniu, ewentualnie akceptacji stanu chwiejnej równowagi, konieczności permanentnego odnawiania dialogu. Przyjęcie perspektywy eutorycznej zakłada deklarację dobrej woli i jednocześnie zrzeczenie się erystycznych pokus.

Zatem z perspektywy eutoryki konflikt - by posłużyć się medycznym językiem - to stan zapalny relacji, który jest albo doraźny, „do wyleczenia", wtedy wymaga znalezienia metod rozwiązania go w sposób możliwie satysfakcjonujący strony, ewentualnie też ustalenia profilaktyki na przyszłość, albo - jeśli dotyczy fundamentalnych wartości i jest nieunikniony - ustalenia zasad funkcjonowania z nim. Tak czy owak zawsze wymaga pracy. Jak słusznie zauważają Dieter-W. Allhoff i Waltraud Allhoff w Sztuce przekonywania do wtasnych racji: „Nie chodzi o unikanie konfliktów albo o usuwanie wszelkich zarzewi konfliktu, centralne pytanie brzmi: Jak traktujemy konflikt?”, i dalej: „Rozwiązać konflikt to najpierw dobrze go poznać" ${ }^{7}$. I choć eutoryka w moim rozumieniu - co chciałabym tu podkreślić - nie jest metodologią rozwiązywania sporów i zażegnywania konfliktów, bo nie one stoją w centrum jej zainteresowania, lecz dobre porozumiewanie się (czemu zamierzam poświęcić odrębne, szczegółowe studium), to siłą rzeczy jakaś część tej dziedziny służyć powinna pomocą w wypadku antagonizmów.

Na czym jednak ma polegać praca z konfliktem? Odpowiedź zależy od tego, z jakim typem konfliktu mamy do czynienia, ile osób on obejmuje i czego dotyczy - bo to przesądza o tym, jaką społecznie akceptowaną formę rozwiązania przyjmiemy, a to są już kwestie przeznaczone dla specjalistów (mediatorów, negocjatorów, moderatorów dyskusji znających określone branże czy grupy społeczne). W każdym razie do dyspozycji są znane metody: deliberacja, mediacja, dialog społeczny, negocjacje, rozmowa terapeutyczna (wspomagana przez różne metody pracy psychoterapeutycznej, jak np. drama czy tzw. otwarty dialog ${ }^{48}$ ). Przyjrzyjmy się im pokrótce:

Deliberacja - jak pisze Jacek Wasilewski - ,jest interakcją społeczną (procesem komunikacji społecznej), w trakcie której wymienia się argumenty i przemyślenia, dokonuje głębokiej refleksji nad stanem rzeczy w otwarty i wielostronny sposób”"49. Polega na swobodnej wymianie

${ }^{46}$ Zob. M. Tokarz, Argumentacja... czy P. H. Lewiński, dz. cyt.

${ }^{47}$ D.-W. Allhoff, W. Allhoff, Sztuka przekonywania do wlasnych racji. Retoryka i komunikacja, przeł. P. Włodyga, Kraków 2008, s. 198 i 203.

${ }^{48}$ Zob. stronę Fundacji Polski Instytut Otwartego Dialogu: http://otwartydialog.pl/o-nas/otwarty-dialog-wprowadzenie/ (dostęp: 30.09.2016).

${ }^{49} \mathrm{~J}$. Wasilewski, Demokracja deliberatywna: stanowiska i nadzieje, w: Konflikty międzygrupowe..., s. 315 i nast. 
stanowisk, w której dochodzi do uzasadniania, wyjaśniania racji, a celem nadrzędnym jest dojście do wspólnej decyzji obowiązującej wszystkich. Każdy uczestnik ma obowiązek wysłuchania cudzych i przestawienia swoich racji na podstawie jawnych i dostępnych informacji, z wykluczeniem przemocy, dominacji, działań zakulisowych. Formą deliberacji jest dyskusja, debata.

Mediacja - podaję za Maciejem Bobrowiczem - to postępowanie dobrowolne i nieformalne, którego celem jest osiągnięcie akceptowanego przez dwie strony rozwiązania konfliktu, z udziałem neutralnego mediatora. Nie rozstrzyga on racji, nie wydaje opinii i nie doradza stronom, a jedynie pomaga w „określeniu ich rzeczywistych potrzeb i interesów” ${ }^{\circ}$. Mediacja na ogół kończy się wzajemną umową stron, rodzajem kompromisu, ewentualnie pojednaniem.

Dialog społeczny - o czym pisze Hanna M. Fedorowicz - „pojmuje się jako interwencję w będących w konflikcie relacjach występujących pomiędzy grupami o różnej tożsamości pod nieobecność otwartej przemocy", celem jest „przeprowadzenie procesów mediacyjnych pomiędzy spolaryzowanymi, osamotnionymi czy skonfliktowanymi grupami o różnej tożsamości. Scalenie zerwanych więzi, nawiązanie nieistniejących wcześniej stosunków, poprawienie chłodnych czy napiętych relacji”, ale też umożliwienie przeżycia związanego z istnieniem „bezpiecznej, neutralnej sfery dyskursywnej” ${ }^{51}$. Podstawą jest naprzemienna praca w mniejszych grupach, oparta na ustrukturyzowanej rozmowie, dyskusji - oraz organizowanie sesji całościowych. Cele są podobne jak w mediacjach, wykraczają jednak poza partykularne interesy ze względu na pracę z grupą.

Negocjacje - jak to pokazują Jolanta Jabłońska-Bonca czy Nic Peeling ${ }^{52}$ - to rodzaj komunikacji wzajemnej, w której, w zależności od modelu negocjacji i przyjętej strategii, dochodzi do osiągnięcia porozumienia, a w jego ramach możliwy jest wzajemny zysk bądź jakaś obustronna strata albo też uzyskanie korzyści przez tylko jedną ze stron. Negocjacje mają swoje etapy i zasady, wymagają wcześniejszego szczegółowego przygotowania stron przed przystąpieniem do właściwych pertraktacji i elastyczności w przyjmowaniu rozwiązań. Cel - w zależności od typu negocjacji - minimalizacja strat lub maksymalizacja zysków ekonomicznych, wypracowanie kompromisu w jakiejś sprawie (przez wzajemne ustępstwa) czy modelu

${ }^{50}$ M. Bobrowicz, Mediacja. Jestem za, Warszawa 2008, s. 18-19.

${ }^{51}$ H. M. Fedorowicz, Dialog społeczny, mediacje $w$ dużych grupach między osobami o różnej tożsamości grupowej, w: Konflikty międzygrupowe..., s. 374 i 378. Zob. też poradnik: K. Zowczak-Jastrzębska, Sztuka dialogu, czyli jak stuchać, aby wszystko zrozumieć, ijak mówić, aby być zrozumianym. Praktyczny poradnik dla uczestników Komisji Dialogu Społecznego, http://www.mazowia.org.pl/files/sztuka_dialogu_3q10...k._zowczak_jastrzebskai.pdf (dostęp: 26.09.2016).

${ }^{52}$ J. Jabłońska-Bonca, Prawnik a sztuka negocjacji i retoryki, Warszawa 2002; N. Peeling, Negocjacje. Co dobry negocjator wie, robi i mówi, tłum. J. Sawicki, Warszawa 2010. 
działania. Zazwyczaj efektem końcowym jest umowa między stronami co do wzajemnych zobowiązań, przedstawiająca zasady i warunki kompromisu, rzadziej - wspólne stanowisko w jakiejś sprawie (skutek konsensusu).

Rozmowa terapeutyczna - monitorowany jednostronnie dialog, podstawa pracy psychologów i psychiatrów; różne odmiany zależne są od przyjętego modelu terapii i założeń teoretycznych. Celem rozmowy terapeutycznej jest zmiana sposobu patrzenia pacjenta, umożliwiająca mu ponowne rozważenie własnych emocji i trudności, lepsze zrozumienie siebie, a w konsekwencji rozwiązanie konfliktu wewnętrznego bądź konfliktu z otoczeniem. Na podstawie swoich doświadczeń terapeutycznych psychiatra Bogdan de Barbaro sformułował nawet Dekalog dobrej rozmowy, przeznaczony dla wszystkich do codziennego użytku. Podstawą jest własna dobra wola i założenie czyjejś dobrej woli, słuchanie, nieocenianie, przyznanie sobie prawa do błędu, szacunek dla człowieka niezależnie od jego czynów, zaciekawienie innym, jasne wyrażanie swojego zdania, przyjęcie wielu możliwych wersji opisu świata, a przy kontrowersji - szukanie tego, co łączy, a także, co wydaje się szczególnie ważne: przyglądanie się rozmowie podczas jej trwania i bycie odpowiedzialnym za jej dobry przebieg 53 .

Natomiast twórca metody zwanej „porozumienie bez przemocy” - Marshall Rosenberg54, psycholog kliniczny i profesjonalny mediator - zaleca swoim rozmówcom pozostającym w sytuacjach konfliktowych cztery etapy - po wstępnym odrzuceniu języka wzajemnych ocen i oskarżeń: 1) obserwację drugiej strony, 2) uświadomienie sobie związanych z inną osobą czy jej zachowaniem uczuć, 3) uświadomienie sobie swoich głęboko ukrytych potrzeb, które ma się w związku z tą osobą i sytuacją (np. potrzeb, których ta osoba nie spełnia lub które narusza czy które chcemy, by zrealizowała), do tego uświadomienie sobie prawdopodobnych potrzeb tej osoby - i nazwanie ich, 4) wyrażenie konkretnej prośby o zmianę czegoś w mówieniu czy zachowaniu. Autor wymienia takie ludzkie potrzeby, jak potrzeba autonomii, świętowania, integralności, współzależności, zaspokojenia fizycznego (powietrza, pożywienia i ruchu), zabawy i wspólnoty duchowej ${ }^{55}$ - ich niezaspokojenie łączy się z negatywnymi uczuciami, które prowadzą do nieporozumień, kłótni. Rosenberg zaleca każdorazowe udzielenie empatii komuś, z kim jesteśmy w konflikcie, by zrozumieć czyjeś emocje i potrzeby, nawet jeśli ten ktoś wydaje się nam zupełnie obcy lub nam grozi. Do tej procedury potrzebne są specjalne ćwiczenia służące zamianie języka agresywnego, nienawistnego na język porozumienia i empatii - ,porozumienie bez przemocy" autor rozumie bowiem właśnie jako proces językowy ${ }^{56}$.

${ }_{53}$ B. de Barbaro, Dekalog dobrej rozmowy, rozm. A. Jucewicz, „Gazeta Wyborcza” 4-5 czerwca 2016, s. 18-19.

${ }^{54}$ M. Rosenberg, To, co powiesz, może zmienić świat. O języku pokoju $w$ świecie konfliktów, przeł. J. Gładyszek, Warszawa 2013.

${ }^{55}$ Tamże, s. $136-137$.

${ }^{56}$ M. Rosenberg, Rozwiązywanie konfliktów poprzez porozumienie bez przemocy, rozm. G. Seils, tłum. B. Wyczesany, Warszawa 2016, s. 27. 
Tym, co łączy wyżej wymienione różne sposoby radzenia sobie z konfliktem, jest: 1) oddzielanie przedmiotu sporu od osób, 2) unikanie wstępnego wartościowania, oceniania, wygaszanie skrajnych emocji, 3) próba nazwania przedmiotu sporu w sposób dający się zaakceptować przez obie strony, 4) wychodzenie poza opozycje binarne w ocenie osób czy sytuacji, szukanie wielu aspektów, 5) podejmowanie prób empatycznego wniknięcia w uczucia, potrzeby, intencje drugiej strony, 6) obiektywizacja sporu przez wprowadzenie wstępnych reguł dyskusji, rezygnację z ,etykietek”, przyjęcie określonych procedur i/lub udział w rozmowach osób trzecich, niezaangażowanych w konflikt.

Warto w tym miejscu zwrócić też uwagę na dwie powiązane ze sobą propozycje retoryczne, wskazujące na przeciwny, niż mowa nienawiści i język konfrontacji, tryb porozumiewania się. Michał Głowiński w artykule pt. Retoryka nienawiści sugeruje stosowanie „retoryki empatii”, której podstawą jest próba zrozumienia drugiej strony i myślenie o niej nie w kategoriach wroga, lecz mającego jakieś swoje racje przeciwnika ${ }^{57}$. Z kolei w nawiązaniu do tej koncepcji Barbara Sobczak stworzyła termin „retoryka pojednania" 58 - ten typ słownego kontaktu opiera się na zmianie myślenia o przeciwniku jako Obcym, a pozostanie przy uznaniu w nim i akceptacji Innego, dalej na unikaniu zawłaszczania, ignorowania czy „naprawiania” Innego ${ }^{59}$ oraz stosowaniu werbalnych (takich np. jak akty obiecywania, zobowiązania, przeprosin), i niewerbalnych „gestów otwarcia”oo. Obie koncepcje jednak akcentują wyraźnie tylko jeden aspekt - albo swego rodzaju „punkt wyjścia” do komunikacji w sytuacji konfliktowej, jakim jest empatia (Głowiński), lub - by tak rzec - „punkt dojścia”, gdy konflikt już istnieje (Sobczak), bo trudno mówić o pojednaniu, gdy ostrego antagonizmu brak. Eutoryka natomiast obejmuje wszystkie działania słowne służące porozumieniu.

Podsumowując: podejście eutoryczne zakłada pewną postawę w komunikacji językowej, dzięki której możliwe jest skuteczne porozumiewanie się bez stosowania presji, języka dominacji, zachowań agresywnych, niestosownych czy wrogich - i albo unikanie ostrych konfliktów, albo umiejętne przechodzenie od konfliktu do sporu i od sporu do rozmowy, tak aby konflikt konstruktywnie zakończyć. Oczywiście podstawą eutoryki są po prostu zasady dobrej rozmowy / dialogu - zostały one scharakteryzowane przez rozmaitych badaczy, głównie językoznawców i psychologów, którzy opisali cały pakiet zagadnień związanych z dobrą komunikacją: od kwestii grzecznościowych i poprawnościowych, przez podstawy efektywności

${ }^{57}$ M. Głowiński, dz. cyt., s. 19-20.

${ }_{5}^{8}$ B. Sobczak, Retoryka pojednania, https://repozytorium.amu.edu.pl/bitstream/10593/12606/1/Sobczak,\%20Retoryka\%20pojednania.pdf (dostęp: 26.09.2016).

${ }^{59}$ Autorka podąża tu drogą rozważań Michała Januszkiewicza nt. reifikacji - zob. B. Sobczak, dz. cyt., s. 280.

${ }^{60}$ Tamże, s. 282. 
i opisy komunikacji twarzą w twarz od strony werbalnej i niewerbalnej, po zagadnienia związane ze skutecznością i perswazją ${ }^{61}$. Istnieją już zresztą podręczniki uczące całościowo dobrej komunikacji62.

Jeśli jednak eutoryka ma zachować swoją specyfikę i zarazem być skuteczną przeciwwagą dla erystyki, to powinna funkcjonować w tych samych, co ona, obszarach, czyli:

1. posługiwać się własną metaforą konceptualną: zamiast uznawać, że „spór to walka”33, trzeba założyć, że „spór to [wspólny] problem” i wskazywać jego przyczyny, rozdzielać na mniejsze zagadnienia oraz próbować znaleźć konkretne rozwiązania;

2. używać wypracowanej na gruncie inwencji retorycznej wiedzy o status do stawiania dobrze dobranych pytań o przedmiot sporu i określania jego przyczyn i okoliczności ${ }^{64}$, by właściwie te przyczyny diagnozować (np. jako prawdziwe, prawdopodobne lub tylko domniemane przez którąś ze stron - czy mylne, bo oparte na fałszywych przesłankach);

3. prowadzić do transformacji dyskursu negatywnego, opartego na dominacji, przesadzie, emocjonalizmach, inwektywach, słownych etykietach i silnych kontrastach czy depersonifikacji przeciwnika - w dyskurs wyważony, zawierający argumenty merytoryczne, otwarty na dialog i zrozumienie inności, oddzielający problemy od ludzi i sprowadzający trudne kwestie do konkretów, faktów, sprawdzonych danych czy twierdzeń. Taka swego rodzaju „translacja” może stanowić zarówno profilaktykę konfliktów (jako efekt pracy nad sobą czy relacją), jak i sposób uniknięcia ich zaostrzenia, gdy się już pojawią - pod warunkiem, że obie strony zgodzą się dokonać samoograniczenia i zmiany;

4. operować sobie właściwymi środkami na poziomie téchne, co dotyczy tak środków werbalnych, jak i niewerbalnych, którymi można się posłużyć, by wesprzeć życzliwą komunikację (jak stosowanie zwrotów grzecznościowych czy upewnianie się, że dobrze się zrozumiało czyjąś wypowiedź, okazywanie zainteresowania itp.).

${ }^{61}$ J. Bartmiński, Etyka słowa a potoczny wzorzec komunikacji, w: Oblicza komunikacji, red. A. Markowski, R. Pawelec, Warszawa 2012. Por. J. Puzynina, O szacunku trochę inaczej, http://www.tokfm.pl/blogi/zmowa/2013/o4/prof_jadwiga_puzynina_o_szacunku_troche_inaczej_na_widoczny_obecnie_brak_szacunku_dla_lekarzy_i_nauczycieli_sklada_ sie_brak_uniwersalnego_szacunku_dla_czlowieka_i_brak_szacunku_dla_wartosci_/1 (dostęp: 30.09.2016). Zob. też A. Załazińska, Niewerbalne znaki sporu - gesty i inne zachowania towarzyszace mowie jako semiotyczne elementy konstytuujące i wyrażające spór, http://www.retoryka.edu.pl/files/far1_2013_art3.pdf (dostęp: 30.09.2016).

${ }^{62}$ Mosty zamiast murów. Podręcznik komunikacji interpersonalnej, tłum. zbior., red. J. Stewart, wyd. IV, Warszawa 2012; J. Gut, W. Haman, Docenić konflikt. Od walki i manipulacji do wspótpracy, Warszawa 1995.

${ }^{63}$ Zob. D. Tannen, Metafory: jesteśmy tym, co mówimy, w: tejże, Cywilizacja kłótni..., s. 26 i nast.

${ }^{64}$ J. Z. Lichański, Retoryka sporu a model rozumowania Karneadesa, „Forum Artis Rhetoricae" 2013, nr 1, s. 7. 
Tak zarysowana eutoryka stanowić może alternatywę dla tych, którzy nie chcą uznawać chwytów erystycznych za „oczywiste” formy komunikacji - i pragną konstruktywnego rozwiązywania konfliktów.

\section{Bibliografia}

Allhoff D.-W., Allhoff W., Sztuka przekonywania do własnych racji. Retoryka i komunikacja, przeł. P. Włodyga, Kraków 2008.

Antropologia stowa. Zagadnienia i wybór tekstów, red. i wstęp G. Godlewski, oprac. G. Godlewski, A. Mencwel, R. Sulima, Warszawa 2003.

Awdiejew A., Strategie konwersacyjne, „Acta Universitatis Lodziensis. Folia Literaria Polonica" 2005, nr 7 .

Barbaro B. de, Dekalog dobrej rozmowy, rozm. A. Jucewicz, „Gazeta Wyborcza” 4-5 czerwca 2016.

Bartmiński J., Etyka słowa a potoczny wzorzec komunikacji, w: Oblicza komunikacji, red. A. Markowski, R. Pawelec, Warszawa 2012.

Batko A., Sztuka perswazji, czyli język wptywu i manipulacji, Gliwice 2005.

Bobrowicz M., Mediacja. Jestem za, Warszawa 2008.

Budzyńska-Daca A., Eristic and Dispute - Applications and Interpretations, „Forum Artis Rhetoricae" 2013, nr 2.

Budzyńska-Daca A., Kwosek J., Erystyka, czyli o sztuce prowadzenia sporów. Komentarze do Schopenhauera, Warszawa 2011.

Bychawska-Siniarska D., Mowa nienawiści - definicja problemu, http://docplayer.pl/15632849-Mowa-nienawisci-definicja-problemu-dominika-bychawska-siniarska.html (dostęp: 15.10.2016).

Carrilho M. M., Korzenie retoryki; starożytność grecka i rzymska, w: M. Meyer, M. M. Carrilho, B. Timmermans, Historia retoryki od Greków do dziś, red. M. Meyer, przeł. Z. Baran, Warszawa 2010.

Danielewiczowa M., Spierać się, kłócić, być w konflikcie. Rozważania semantyczne, w: Wspótczesne dyskursy konfliktu. Literatura - Język - Kultura, red. W. Bolecki, W. Soliński, M. Gorczyński, Warszawa 2015.

Darczewska J., Anatomia rosyjskiej wojny informacyjnej. Operacja krymska - studium przypadku, Warszawa 2014, http://www.osw.waw.pl/sites/default/files/anatomia_rosyjskiej_wojny_informacyjnej.pdf (dostęp: 30.09.2016).

Dobek-Ostrowska B., Fras J., Ociepka B., Teoria i praktyka propagandy, Wrocław 1999.

Domańska E., Historia egzystencjalna, Warszawa 2012.

Duke G., The Sofist (Ancient Greek), in: Internet Encyclopedia of Philosophy, http://www. iep.utm.edu/sophists/ (dostęp: 29.09.2016).

Dziugieł I., Mediacja w postępowaniu przygotowawczym, Szczytno 2004.

„Forum Artis Rhetoricae” 2013, nr 1, 2 [numery poświęcone sporom i konfliktom].

Głowiński M., Retoryka nienawiści, „Nauka” 2007, nr 2.

Gut J., Haman W., Docenić konflikt. Od walki i manipulacji do wspótpracy, Warszawa 1995.

Hogan K., Psychologia perswazji. Strategie i techniki wywierania wptywu na ludzi, przeł. A. Dziuban, Warszawa 2005.

Ideologie w stowach i obrazach, red. I. Kamińska-Szmaj, T. Piekot, M. Poprawa, Wrocław 2008.

Jabłońska-Bonca J., Prawnik a sztuka negocjacji i retoryki, Warszawa 2002.

Jabłoński W., Kreowanie informacji. Media relations, Warszawa 2007.

Klemperer V., LTI. Notatnik filologa, tłum. J. Zychowicz, Warszawa 1989.

Kochan M., Pojedynek na stowa. Techniki erystyczne w publicznych sporach, Kraków 2005. 
Konflikty międzygrupowe. Przejawy, źródła i metody rozwiązywania, red. K. Skarżyńska, U. Jakubowska, J. Wasilewski, Warszawa 2007.

Korwin-Piotrowska D., Białe znaki. Milczenie $w$ strukturze i znaczeniu utworów narracyjnych, Kraków 2015.

Kotarbiński T., Definicja i cel studiowania erystyki. Chwyty czysto techniczne. Fortele nielojalne. Charakterystyka dyskusji rzeczowej, w: tegoż, Kurs logiki dla prawników, Warszawa 1961.

Kowalski S., Tulli M., Zamiast procesu. Raport o mowie nienawiści, Warszawa 2003.

Kövecses Z., Język, umyst, kultura. Praktyczne wprowadzenie, przeł. A. Kowalcze-Pawlik, M. Buchta, Kraków 2011.

Lewiński P. H., Neosofistyka. Argumentacja retoryczna $w$ komunikacji potocznej, Wrocław 2012.

Levinson S. C., Pragmatyka, przeł. T. Ciecierski, K. Stachowicz, Warszawa 2010.

Lichański J. Z., Retoryka sporu a model rozumowania Karneadesa, „Forum Artis Rhetoricae" 2013, $\mathrm{nr} 1$.

Markowski A., Kultura języka polskiego. Teoria. Zagadnienia leksykalne, Warszawa 2005.

Mechanizmy perswazji i manipulacji. Zagadnienia ogólne, red. G. Habrajska, Łask 2007.

Mielczarski C., Sofiści i polityka, Warszawa 2010.

Mosty zamiast murów. Podręcznik komunikacji interpersonalnej. Podręcznik komunikacji interpersonalnej, tłum. zbior., red. J. Stewart, wyd. IV, Warszawa 2012.

Mouffe Ch., Agonistyka. Polityczne myślenie o świecie, przeł. B. Szelewa, Warszawa 2015.

Narracja jako sposób rozumienia świata, red. J. Trzebiński, Gdańsk 2002.

O'Connor J., Seymour J., NLP. Wprowadzenie do programowania neurolingwistycznego, przeł. B. Mizia, Poznań 2013.

Peeling N., Negocjacje. Co dobry negocjator wie, robi i mówi, tłum. J. Sawicki, Warszawa 2010.

Pietrzyk M., Retoryka tolerancji, Warszawa 2015.

Pratkanis A., Aronson E., Wiek propagandy. Używanie i nadużywanie perswazji na co dzień, tłum. J. Radzicki i M. Szuster, Warszawa 2003.

Puzynina J., Mowa nienawiści a etyka stowa ZES, http://www.etykaslowa.edu.pl/wpcontent/uploads/2016/05/Mowa-nienawi\%C5\%9Bci-a-etyka-s\%C5\%82owa.pdf (dostęp: 27.09.2016).

Puzynina J., O szacunku trochę inaczej, http://www.tokfm.pl/blogi/zmowa/2013/o4/ prof_jadwiga_puzynina_o_szacunku_troche_inaczej_na_widoczny_obecnie_brak_ szacunku_dla_lekarzy_i_nauczycieli_sklada_sie_brak_uniwersalnego_szacunku_ dla_czlowieka_i_brak_szacunku_dla_wartosci_/1 (dostęp: 30.09.2016).

Rambiert A., Bieg Pawła z Tarsu, czyli spotkania z greckq agonistyka, Wrocław 2013, https:// depot.ceon.pl/bitstream/handle/123456789/6535/Bieg_Pawla_z_Tarsu_czyli_spotkania_z_grecka_agonistyka.pdf?sequence=1\&isAllowed=y (dostęp: 29.09.2016).

Retoryka i etyka, red. B. Sobczak i H. Zgółkowa, Poznań 2009.

Rosenberg M., To, co powiesz, może zmienić świat. Ojęzyku pokoju w świecie konfliktów, przeł. J. Gładyszek, Warszawa 2013.

Rosenberg M., Rozwiązywanie konfliktów poprzez porozumienie bez przemocy, rozm. G. Seils, tłum. B. Wyczesany, Warszawa 2016.

Schopenhauer A., Erystyka, czyli sztuka prowadzenia sporów, przeł. B. i L. Konorscy, wyd. III, przedm. T. Kotarbiński, Kraków 1984.

Sobczak B., Retoryka pojednania, https://repozytorium.amu.edu.pl/bitstream/10593/12606/1/Sobczak,\%2oRetoryka\%2opojednania.pdf (dostęp: 26.09.2016).

Stelmach J., Brożek B., Negocjacje, Kraków 2014.

Sztuka perswazji. Socjologiczne, psychologiczne i lingwistyczne aspekty komunikowania perswazyjnego, red. R. Karpiel i K. Leszczyńska, Kraków 2004.

Sztumski J., Konflikty społeczne i negocjacje jako sposoby ich przezwyciężania, Częstochowa 2000. 
Tannen D., Cywilizacja kłótni. Jak powstrzymać amerykańska wojnę na słowa, przeł. P. Budkiewicz, Poznań 2003.

Tischner J., Filozofia dramatu. Wprowadzenie, Paris 1990.

Tokarz M., Argumentacja. Perswazja. Manipulacja, Gdańsk 2006.

Ugresić D., Kultura kłamstwa, tłum. D. J. Ćirlić, Wrocław 1998.

Wasilewski J., Retoryka dominacji, Warszawa 2006.

Wierzbicka A., Genry mowy, w: Tekst i zdanie.Zbiór studiów, red. T. Dobrzyńska i E. Janus, Wrocław 1983.

Wilkoń A., Gatunki mówione, w: Porozmawiajmy o rozmowie. Lingwistyczne aspekty dialogu, red. M. Kita i J. Grzenia, Katowice 2003.

Załazińska A., Niewerbalne znaki sporu - gesty i inne zachowania towarzyszace mowie jako semiotyczne elementy konstytuujące i wyrażajace spór, http://www.retoryka. edu.pl/files/far1_2013_art3.pdf, (dostęp: 30.09.2016).

Zowczak-Jastrzębska K., Sztuka dialogu, czyli jak stuchać, aby wszystko zrozumieć, i jak mówić, aby być zrozumianym. Praktyczny poradnik dla uczestników Komisji Dialogu Społecznego, http://www.mazowia.org.pl/files/sztuka_dialogu_3q10...k._zowczak_ jastrzebskai.pdf, (dostęp: 26.09.2016). 